\title{
DIVERSIFIED PRODUCTION AND BIOENERGY CONVERSION FOR RURAL DEVELOPMENT
}

Gennadii GOLUB, Tractors, Automobiles and Bioenergosystem Department, National University of Life and Environmental Sciences of Ukraine, Heroyiv Oborony str., 15, 03041 Kyiv, Ukraine, e-mail: gagolub@ukr.net

Savelii KUKHARETS, Faculty of Engineering and Energy, Zhytomyr National Agroecological University, Staryi Blvd. 7, UA-10008, Zhytomyr, Ukraine, e-mail: saveliy_76@ukr.net (corresponding author)

Yaroslav YAROSH, Faculty of Engineering and Energy, Zhytomyr National Agroecological University, Staryi Blvd. 7, UA-10008, Zhytomyr, Ukraine, e-mail: yaroslav.yarosh76@gmail.com

Oksana ZAVADSKA, Tractors, Automobiles and Bioenergosystem Department, National University of Life and Environmental Sciences of Ukraine, Heroyiv Oborony str., 15, 03041 Kyiv, Ukraine, e-mail: oksanalutak@ukr.net

The mechanical and technological grounds for the formalization of agroecosystem structure have been substantiated in the research. The paper presents the simulation model of an agroecosystem functioning based on growing of winter wheat, maize for silage as well as of grain, winter rape, oats, sugar beets and perennial herbs. The model anticipates the production of pork, beef, fish, chicken, milk, eggs, oil, sugar and honey as well as growing of mushrooms and production of compost. Besides, the given model anticipates the production of diesel biofuel and bioethanol in the amount necessary for providing mobile machines with power, as well as the production of biogas for receiving heat and electricity. The model suggests using the updated equipment for the production of bioenergy resources.

Keywords: agro-ecosystems, energy, conversion, straw, biodiesel, biogas

\section{INTRODUCTION}

The mankind has been faced with several problems: providing the population with food stuff (food problem), providing the technological processes and everyday life with energy resources (energy problem) and the conservation of the environment (ecological problem) (Golub, Kukharets, Yarosh, Kukharets, 2017; Pollmann, Podruzsik, Fehér, 2014). To solve these problems we need to overcome the contradiction which lies in the fact that an increase in the production of food stuff or in the production and in utilization of energy results in disturbing the ecological balance and in the deterioration of the environment, and conversely keeping to ecological demands under the existing level of population growth will result in food and energy deficit.

The modern agriculture is partly solving the food problem (Golub, Kukharets, Yarosh, Kukharets, 2017; Geletuha, Zhelezna, 2014). But the level of providing the agrarian production with energy made of raw materials is law. For example, animal breeding branch of Ukraine producing a great amount of organic wastes, has significant resources for biogas production, at the same time the level of biogas production made of manure is very low (Geletukha, Kucheruk, Matveev, 2013; Geletuha, Zhelezna, 2014; Borja, Rincón, 2017). The energy potential of crop growing branch which is based on straw utilization as fuel as well as on the production of diesel biofuel is rather high (Geletuha, Zhelezna 2014; Baranauskas, Ilves, Küüt, Olt, 2015; Ivanova, Stoyanov, 2016; Baskar, Aiswarya, 2016), but its utilization in Ukraine does not exceed 3\%.

A typical agroecosystem anticipates crop growing in a corresponding crop rotation and it provides the production of plants produce, fodder for animal breeding and poultry breeding as well as energy resources. The energy basis for the agroecosystem is heat and energy production from biogas received from manure and chicken faeces fermentation, as well as from the utilization in a scientifically based limits of a non- grain part of the yield in the form of round balls, wads, straw cut, or granules, cubes and generator gas, produced from straw utilization for heat use. The raw basis for the production of liquid fuel- diesel biofuel and bioethanol is also a constituent part of agroecosystem. The diversification of the areas of focus in the agricultural production is a serious financial precondition for soil fertility sustaining on the basis of compost production by using the biological conversion of an organic raw material (Di Maria, Sordi, Micale, 2012; Golub, Kukharets, Yarosh, Kukharets, 2017).

But the estimation of technical and economic efficiency of agroecosystem functioning with multifunctional production of the agrarian produce as well as of biofuel, needs further specification.

Copyright (C) 2017 The Authors. Published by Aleksandras Stulginskis University. This is an open-access article distributed under the terms of the Creative Commons Attribution License (CC-BY 4.0), which permits unrestricted use, distribution, and reproduction in any medium, provided the original author and source are credited. 


\section{MATERIALS AND METHOD}

The simulation model of agricultural production functioning (Fig.1) includes crop rotation in growing the basic agricultural crops, as well as it anticipates the production of pork, beef, fish and chicken, milk, eggs, oil, honey and mushrooms. The given model anticipates the production of diesel biofuel and bioethanol in the amount necessary for providing mobile machines with energy, the production of biogas for further receiving of energy and heat, as well as burning of round balls and straw cuts for receiving heat and electricity. The model anticipates crops drying on account of own energy resources.

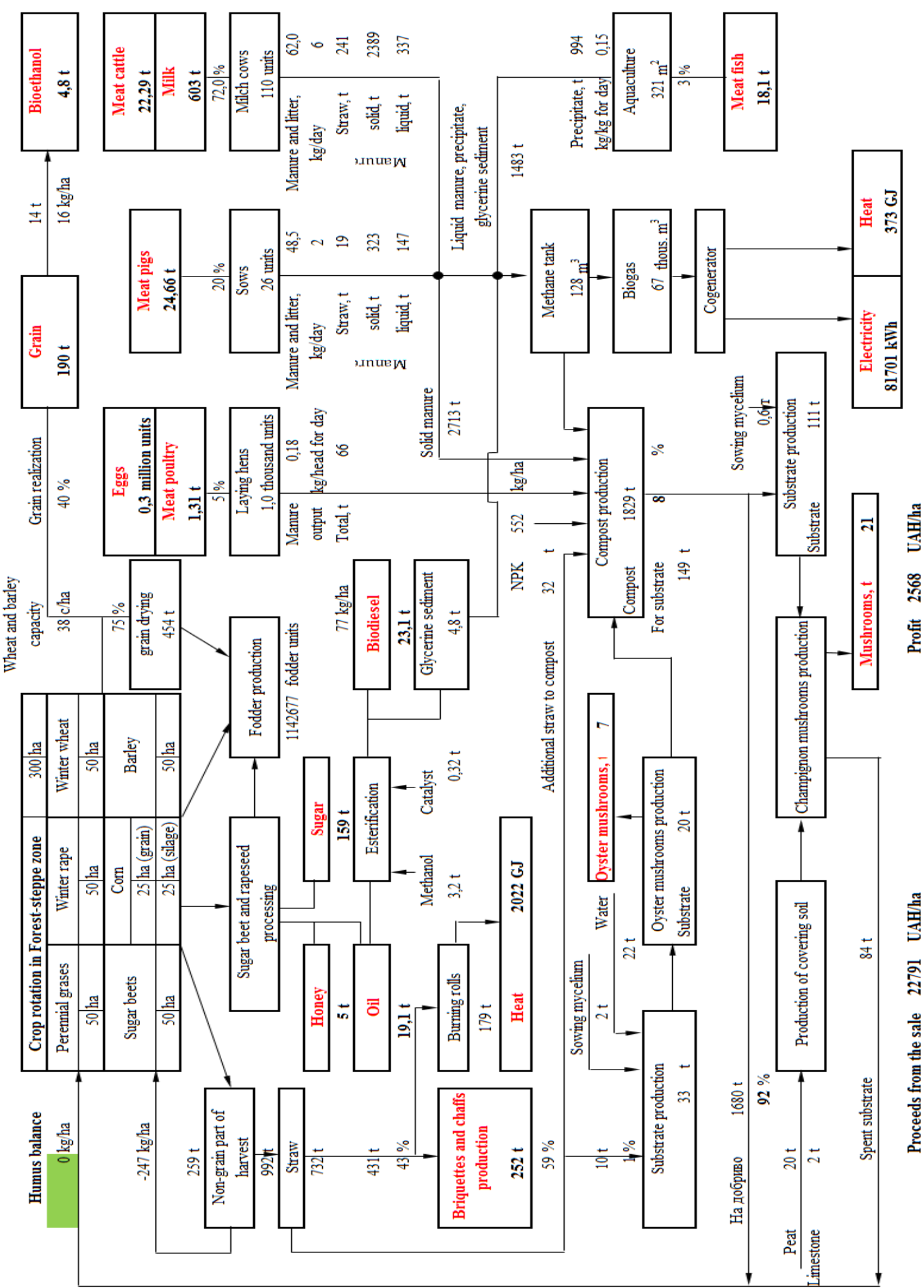

Figure 1. Conception of diversified production of agricultural goods and biofuel in agroecosystems 
The analysis anticipates the functioning of 3 variants of the agroecosystem:

- with the production of plants produce, animal produce and biofuel (variant 1);

- with the production of the plants and animal produce but without the production of biofuel (variant 2);

- with the production of plants produce but without the production of animal produce and biofuel (variant 3 ).

The main efficiency indexes of the agrarian production functioning were established on the basis of the developed computer simulation model of the agroecosystem functioning with a diversified (multifunctional) production of the agrarian produce and of biofuel.

The determination of technical and economic efficiency of the agroecosystem functioning with diversified (multifunctional) production of the agrarian produce and of biofuel was performed on the basis of imitative computer simulation.

\section{RESULTS AND DISCUSSION}

The parameters analysis of the agroecosystem functioning, received on the basis of simulation, made it possible to receive graphically the dependence of humus balance of the basic crop yields - winter wheat.

The graphic analysis enables us to conclude that the best indexes as for humus balance are achieved in an agroecosystem free of biofuel production. But a positive humus balance is achieved in the agroecosystem with biofuel production when grain yields are more than 30 ha. In an agroecosystem without animal breeding it is impossible to have a positive humus balance.

The highest profit in terms of per ha is achieved in agroecosystem with biofuel production (Fig. 3).

The highest economic effect can be achieved in a balanced agroecosystem, which combines crop growing, animal breeding and biofuel production, herewith having provided non-deficit humus balance.

The level of fuel supply and heat supply can be shown graphically (Fig.4) and by dependence:

$$
\begin{aligned}
& E S=27,905 \ln (u)-77,951 ; \\
& H S=196,59 \ln (u)-485,68,
\end{aligned}
$$

where ES is the level of energy supply, \%; HS is the level of heat supply, \%; u is basic crop yields (winter wheat), centner per ha.

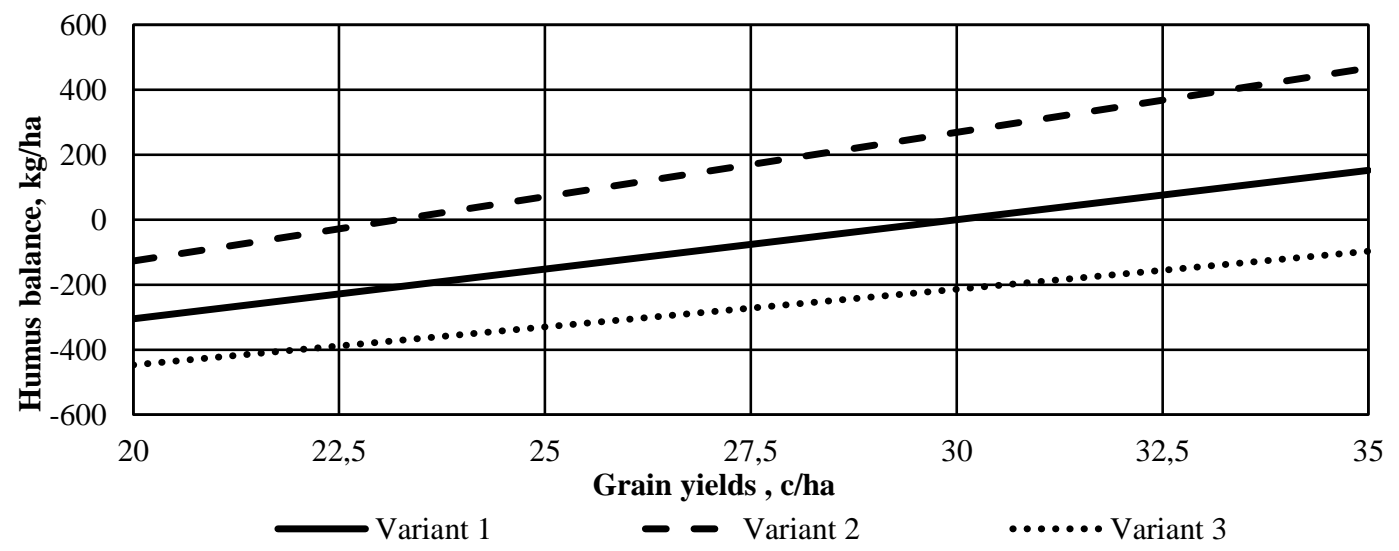

Figure 2. The dependence of humus balance on the basic crop yields.

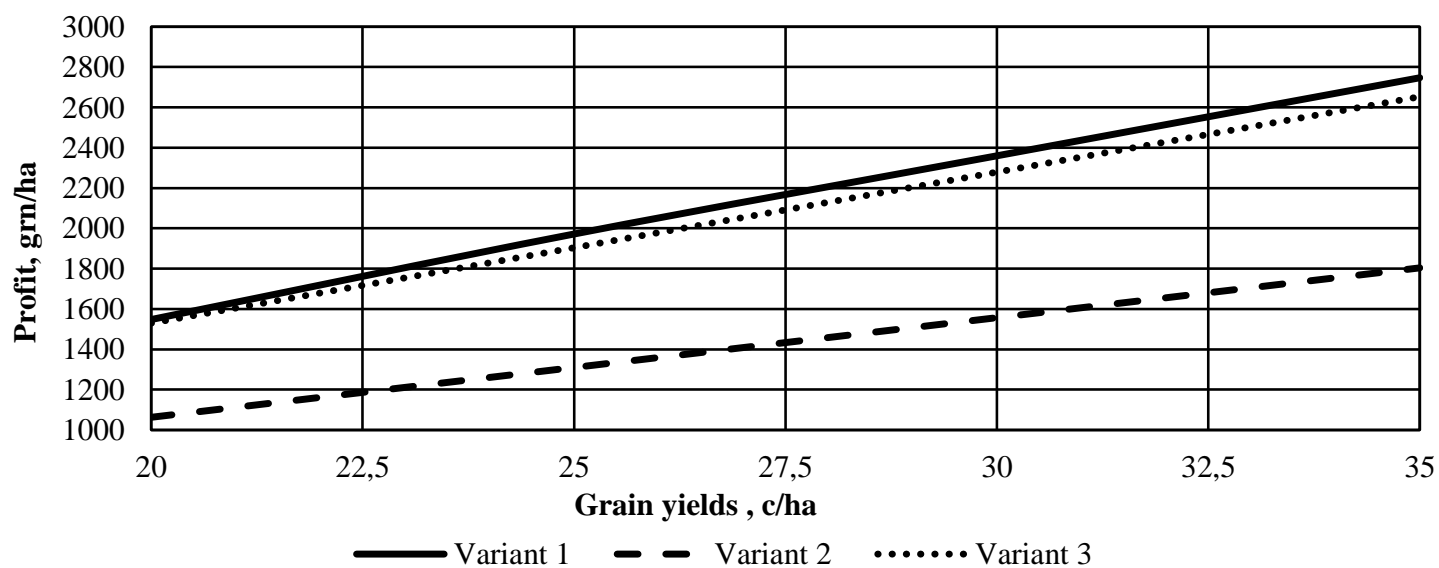

Figure 3. The dependence of profit of the basic crop. 


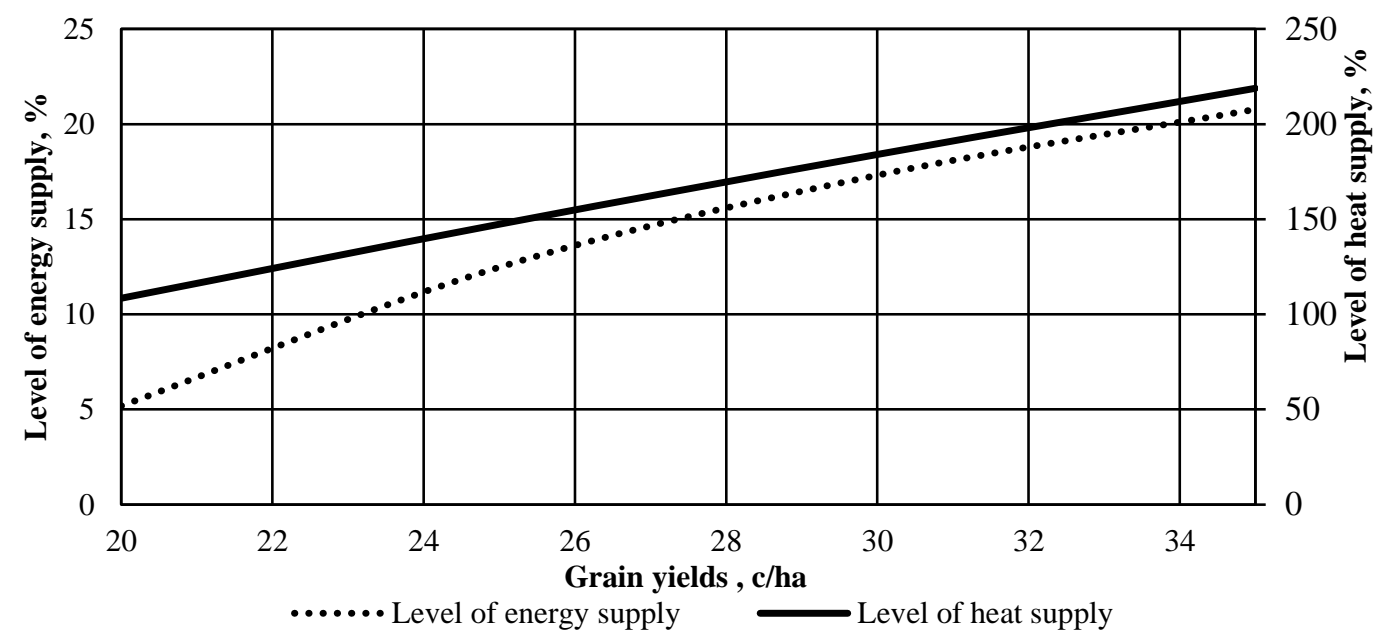

Figure 4. The level of energy and heat supply (without transforming the excess of heat energy into electricity).

Agroecosystem is capable to provide itself with necessary heat energy under grain yields of 20 centner per ha and more, and under the condition of higher yields the excess of heat energy can be transformed into electrical one, herewith having increased the level of energy supply.

The structure of financial income, under the condition of agroecosystem functioning, can be shown graphically (Fig. 5).

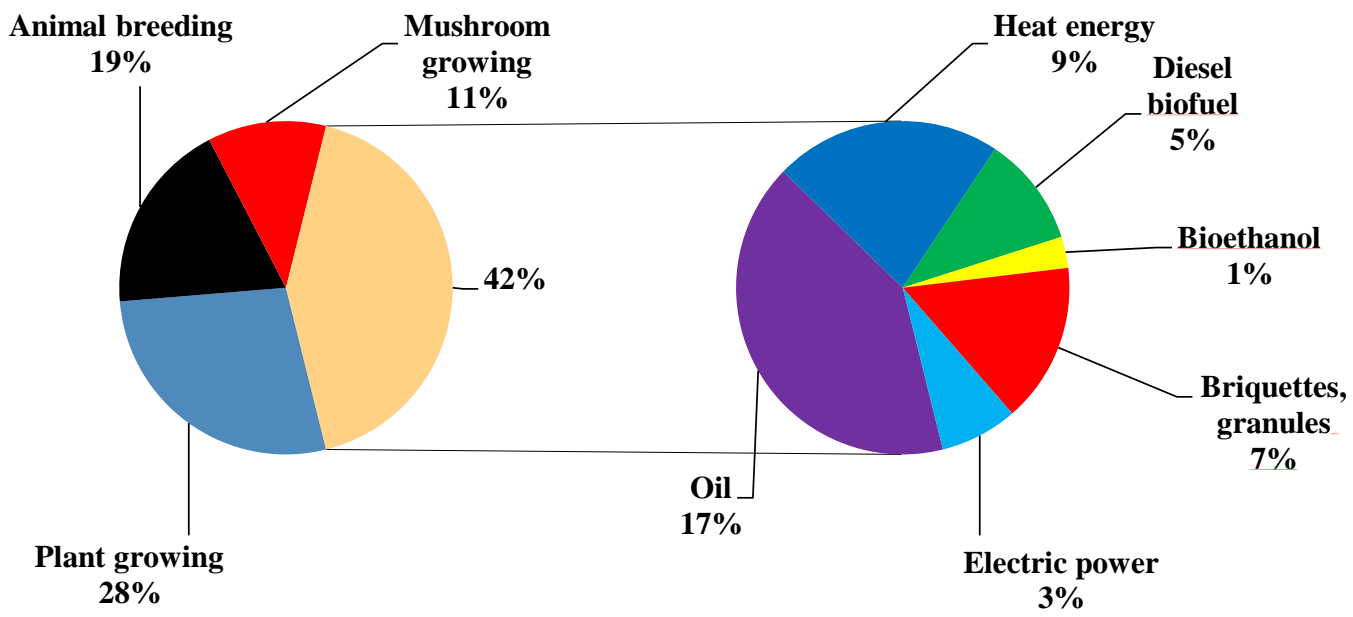

Figure 5. The structure of received profit from agricultural products and biofuels manufacturing in agroecosystems

The graphic shows that up to $42 \%$ of all financial investments into an agroecosystem can be provided on account of biofuel production and utilization.

\section{CONCLUSIONS}

Computer simulation model of agroecosystem with multidisciplinary production of agricultural products and biofuels was created. Model allows determining of main functioning efficiency indicators of agricultural production.

The greatest economic effect can be achieved in a balanced agroecosystem, which combines crop growing, animal breeding and biofuel production, herewith having provided a non-deficit humus balance. Under winter wheat yields of 38 c per ha the income for the balanced agroecosystem with the biofuel production is $2568 \mathrm{hr}$ per ha, which is $51.6 \%$ higher than for an agroecosystem without biofuel production. Up to $42 \%$ of all financial investments into the agricultural production can be saved under the condition of biofuel producing and utilizing.

\section{REFERENCES}

1. Golub, G. A., Kukharets, S. M., Yarosh, Y. D., Kukharets, V. V., 2017. Integrated use of bioenergy conversion technologies in agroecosystems. INMATEH - Agricultural Engineering, Vol. 51, No. 1, pp. 93-100

2. Pollmann, O., Podruzsik, S., Fehér, O., 2014. Social acceptance of renewable energy: some examples from Europe and developing Africa. Society and Economy, Vol. 36, No. 2, pp. 217-231.

3. Geletuha, G.G., Zhelezna, T.A., 2014. The Perspectives of Agricultural Wastes Utilization for Energy Production in Ukraine. Analitical Notes ASL, No. 7, 33 p. 
4. Geletuha, G.G., Kucheruk, P.P., Matveiev, U.B., 2013. The Perspectives of Biogas Production and Utilization in Ukraine. Analitical Notes ASL, No. 4, 22 p.

5. Geletuha, G.G., Kucheruk, P.P., Matveiev, U.B., 2013. Development of biogas technology in Ukraine and Germany: normativelegal framework and prospects. Kyiv - Hyultsov, 75 p.

6. Borja, R., Rincón, B., 2017. Biogas Production. Instituto de la Grasa (CSIC), Seville, Spain. Reference Module in Life Science

7. Ivanova, B., Stoyanov, S., 2016. Mathematical model formulation for the design of an integrated biodiesel-petroleum diesel blends system. Energy, Vol. 99, pp. 221-236, https://doi.org/10.1016/j.energy.2016.01.038

8. Baskar, G., Aiswarya, R., 2016. Trends in catalytic production of biodiesel from various feedstocks. Renewable and Sustainable Energy Reviews, Vol. 57, pp. 496-504. https://doi.org/10.1016/j.rser.2015.12.101

9. Baranauskas, R., Ilves, R., Küüt, A., Olt, J., 2015. Influence of the biodiesel fuels with multifunctional additives on the diesel engine efficiency. Proceedings of the 7th International Scientific Conference Rural Development 2015. https://doi.org/10.15544/RD.2015.018

10. Di Maria, F., Sordi, A., Micale, C., 2012. Energy production from mechanical biological treatment and Composting plants exploiting solid anaerobic digestion batch: An Italian case study. Energy Conversion and Management, Vol. 56, pp. 112-120. https://doi.org/10.1016/j.enconman.2011.11.023 